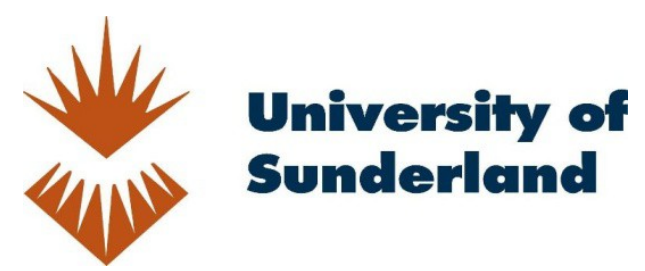

Pappas, Nikolaos (2017) The complexity of purchasing intentions in peer-to-peer accommodation. International Journal of Contemporary Hospitality Management, 29 (9). pp. 2302 2321. ISSN 0959-6119

Downloaded from: http://sure.sunderland.ac.uk/id/eprint/13979/

Usage guidelines

Please refer to the usage guidelines at http://sure.sunderland.ac.uk/policies.html or alternatively contact sure@sunderland.ac.uk. 


\title{
The complexity of purchasing intentions in peer-to-peer accommodation
}

\begin{abstract}
Purpose: The study aims to examine the complexity of attribute configurations affecting tourism decisions related to peer-to-peer accommodation and the sharing economy in destinations affected by recession.

Design/methodology/approach: Based on chaos and complexity theories this nonparametric research examines the perspectives of 352 peer-to-peer accommodation holidaymakers in Athens, Greece. Using fuzzy-set Qualitative Comparative Analysis (fsQCA), the study examines the complex relations between social and economic aspects, benefits, risks, and consumer trust with regard to purchasing intentions. The paper also compares fsQCA with the dominant linear methods of analysis (regression; Cramer's V) and highlights fsQCA's suitability when dealing with tourism complexity.
\end{abstract}

Findings: The results reveal three configurations explaining the attributes of holidaymakers' tourism decisions characterised by socio-economic orientation, trust formulation, and price sensitivity. They also highlight the superiority of fsQCA towards conventional linear analyses in complexity aspects.

Research limitations/implications: The examination of the complexity concept using fsQCA can provide a better understanding of the influence of attributes which affect tourism decisions especially for countries suffering from deep recession such as Greece. Still, due to the lack of fsQCA implementation in tourism studies its full potential needs to be further examined.

Originality/value: In terms of the literature, the study provides an understanding of the complexity formulation of tourism decisions during recession, with special focus on the sharing economy. It further explores the attributes that affect tourism decisions and associated linkages. Methodologically, the study highlights the value of fsQCA and its advantages compared to conventional methods of correlational analysis. It also progresses from fit to predictive validity for the models suggested.

Keywords: Sharing economy, Chaos Theory, Complexity Theory, Holidaymakers, fuzzy-set Qualitative Comparative Analysis, Greece

Paper type: Research paper 


\section{Introduction}

The sharing economy refers to exchange forms facilitated through the use of online platforms, and encompasses a diversity of activities that broadly aim to open access to under-utilised resources through what is termed 'sharing' (Richardson, 2015). Interest in the impact and nature of the sharing economy is rapidly growing, since the two dominant sharing economy platforms (Airbnb and Uber) have transformed within five years from entrepreneurial start-up companies to multi-billion internationally operating corporations (Konrad and Mac, 2014; Lashinsky, 2015). The development of the sharing economy is likely to transform the global tourism system and the way it serves societal needs (Martin, 2016). More specifically, Heinrichs (2013, p.228) perceives the sharing economy as a "pathway to sustainability" since it promotes sustainable consumption practices. Moreover it disrupts the driving unsustainable trends of hyper-consumption in modern economies (Botsman and Rogers, 2010), enabling a cultural shift away from assets owned by consumers towards the access of assets shared by consumers (Martin, 2016).

Conversely, the sharing economy concept has faced considerable criticism since it opened up unregulated peer-to-peer marketplaces producing adverse social impacts (Schofield, 2014), and leading to the commercialisation of life aspects that were previously beyond market reach (Morozov, 2013). For example, in Berlin, Germany, the success of short-term rentals through Airbnb has led to a remarkable fall in the number of properties available for long-term rental periods, forcing the local authorities to ban the short-term let of entire apartments to tourists without a city permit (Payton, 2016). Berlin's example has been followed by several other German cities such as Hamburg, Munich, and Stuttgart, but despite the ban and prospective fines, the considerably high profits led many residential property owners to continue renting them through Airbnb (The Local, 2016).

The current recession has boosted the sharing economy's development especially in areas that have suffered from the economic crisis, leading locals to exploit their property seeking a source of supplementary income (Johanson, 2013). With regard to consumers, peer-to-peer accommodation offers considerably low revenue cost for individuals to profitably list remnant inventory online (Zervas et al., 2016), and gives the opportunity for an enhanced reach through the reduction of search costs (Bakos, 1997), something which is of substantial importance in periods of economic crisis (Beritelli and Schegg, 2016). As a result, peer-to-peer accommodation has rapidly developed in Greece, a country that has been severely hit by the current economic crisis (Pappas, 2015a). The majority of Greek peer-to-peer accommodation is offered in Athens where more than 2300 properties are listed only on Airbnb (Hellenic Chamber of Hotels, 2015).

On these grounds, the aim of this article is to evaluate the complexity of attribute configurations influencing peer-to-peer accommodation consumer decisions and the sharing economy in Athens, a city that has been heavily affected by the current recession. More specifically it examines the influence of the economic and social aspects, benefits, risks, and trust concerning the purchasing intentions of adult holidaymakers who have selected peer-to-peer accommodation in Athens. The contribution of the study lies in both the theoretical and methodological domains. In terms of the literature, it provides an understanding of the complexity of the formulation of tourism decisions during recession, with special reference to the 
sharing economy. Methodologically, it employs fuzzy-set Qualitative Comparative Analysis (fsQCA) which is new to the study of tourism and hospitality, also providing a comparison with regression and Cramer's V, the most commonly used linear methods of correlational analysis. It further progresses from fit to predictive validity for the suggested models.

\section{Chaos and complexity}

The theory of chaos "proposes a broad set of loosely related theoretical and metatheoretical orientations to the behaviour of complex non-linear systems" (Seeger, 2002, p.329). More specifically, it proposes that even small changes may produce significant diverging outcomes to dynamic systems making it impossible to predict behavioural patterns for a long time period (Kellert, 1993). Still, a chaotic system is dependent on its initial conditions, and they appear to be random but actually do not lack order (Levy, 1994). Thus, chaos theory is used in management in order to explain the complexity in organisations (Meyer et al., 2005), and complex organisational dynamics (Xitong et al., 2009). Complexity theory has emerged from the theory of chaos, focusing on systems with complex characteristics, since these systems have structure and permit improvement although they are hard to predict (Zahra and Ryan, 2007). As Hock (1999) indicates, the chaordic system, meaning the blending between chaos and order, is a new concept emerging from the theories of chaos and complexity, and is based on their very strong relationship.

The main difference between chaos and complexity is that, with chaos, simple systems produce complicated behavioural patterns that cannot be predicted, whilst complexity theory deals with the way multi-elemental systems lead to relative behavioural predictability (Baggio, 2008). As Wu et al. (2016) suggest, the trajectories of complex systems are always directed by complex and contingent causes (indicators). The complexity of chaordic outcomes can produce unpredictable and dramatic conditions, but the emerging dynamic systems are not completely uncontrolled, since some kind of order is present (Zahra and Ryan, 2007). Thus, in the social sciences, the theory of complexity and QCA can be used to explain consumer evaluations, attributes, and intentions through the implementation of alternative nonlinear (asymmetric) combinations of various indicators (Wu et al., 2014).

\section{Chaos and complexity in tourism}

The traditional research approach in tourism assumes considerable stability, and predominantly uses linear analysis as the appropriate profile for stable systems (Papatheodorou and Pappas, n.d.) even if tourism initiates sustained instability since it is constantly in flux with outliers (Russel and Faulkner, 2004). Tourist behaviour can be systemically affected by both endogenous and exogenous factors (Boukas and Ziakas, 2014). These factors appear to have stable features as some kind of order seems to exist in their configuration (Olmedo and Mateos, 2015). Moreover, complex systems in tourism and hospitality may be highly sensitive to apparently unrelated events which, even despite their low significance, may trigger significant changes (Baggio and Sainaghi, 2011). As a result, it is essential to understand the component parts within the complex systems of tourism, the underlying values, their interrelationships, and the way perceptions and issues are formulated (McDonald, 2009). Thus, nearly two decades ago, Faulkner and Russell (1997) proposed that chaos and complexity theories could be used as alternative frameworks for the examination of tourist behaviour aiming to better comprehend the dynamic systems in 
tourism. This is supported by Laws and Prideaux (2005), since they consider that the extent of complexity in behavioural patterns questions the adequacy of the Newtonian (linear) analysis, indicating the need for asymmetric (non-linear) analysis. In tourism and hospitality, complexity theory is able to provide significant information concerning the way that behavioural patterns are formulated and expressed (Russell and Faulkner, 2004), leading to a better understanding of the changing dynamics of tourism (Faulkner and Russell, 2000).

\section{Study tenets}

In the service sector the term 'tenet' is used in research in order to express the testable precepts dealing with the theory of complexity (Papatheodorou and Pappas, n.d.). As Wu et al. (2014) suggest, consistency metrics or statistical hypotheses are not usually included when the adequacy testing for complex configurations is predicting outcome scores. According to configuration theory the same set of causal factors is likely to lead to different outcomes, in terms of the way these factors are arranged (Ordanini et al., 2014). The current study examines important attributes that affect the decisionmaking of peer-to-peer accommodation holidaymakers, as highlighted by the relevant literature (Gefen et al., 2003; Kim et al., 2008; Tussyadiah and Pesonen, n.d.; Sanchez et al., 2006; Sparks and Browning, 2011). As a result, all binary states' combinations (presence or absence of their configurations) were examined in terms of holidaymakers' peer-to-peer accommodation purchasing intentions in Athens. The five examined attributes were: Social Aspects, Economic Aspects, Benefits, Risks, Trust. The study formulated the following tenets:

T1: The same attribute can determine a different purchasing intention for peer-to-peer accommodation holidaymakers depending on its configuration/interaction with other attributes.

T2: When two or more simple conditions create a complex configuration, an outcome condition can have a consistently high score (recipe principle).

T3: Complex configurations/interactions affect the purchasing intentions of peer-topeer accommodation holidaymakers.

T4: The simple conditions within different combinations of

configurations/interactions can positively or negatively affect the purchasing intentions of peer-to-peer accommodation holidaymakers.

T5: A sufficient purchasing intention for peer-to-peer accommodation model is not necessary to occur by having a high outcome score (equifinality principle).

T6: When the Y scores are high, a given recipe for holidaymakers' purchasing intention of peer-to-peer accommodation is not relevant for all cases.

\section{The sharing economy and tourism}

During the last few years, public interest in the sharing economy and its notable impacts on the current socio-economic system has grown significantly, but the relevant literature on tourism has been considerably fragmented (Cheng, 2016). Despite the lack of relevant literature, tourism and hospitality have emerged as the pioneering sectors with regard to growth of the sharing economy, allowing residents and tourists to share their residential properties (OECD, 2016; Sigala, n.d.).

Airbnb is the main company operating in the accommodation domain, and has successfully revolutionised the way in which the sharing economy is perceived, as within a short period of time, it has topped the world leading traditional international 
hotel chains through an unprecedented expansion (Clampet, 2015). The main reason for this success is the beneficial impact of the sharing economy for both locals and tourists. In terms of locals, the sharing economy has significantly increased the available supply options since it is much easier to start a tourism and/or hospitality business because start-up costs are considerably lower (Nabler, 2014). From a consumer perspective, peer-to-peer accommodation has substantially changed travel patterns through a cost reduction for accommodation and a considerable increase of social encounters with locals (Tussyadiah and Pesonen, 2015). Consumers that select peer-to-peer accommodation instead of traditional establishments, derive enjoyment from the experience as a result of amusement and curiosity (Lindenberg, 2001), and to reduce the environmental impacts of overconsumption, a communal desire tied with sharing economy (Gansky, 2010). In addition to monetary benefits (Möhlmann, 2015) peer-to-peer accommodation brings together multiple clients and retailers, and through the reduction of information asymmetry it creates more competitive markets (Koopman et al., 2014). Several other reasons such as the desire for socialisation and the sense of belonging (Möhlmann, 2015), the need for travel experience authenticity (Kim et al., 2015), and the amenities and convenience of accommodation location (Tussyadiah, 2016) lead many tourists to prefer peer-to-peer accommodation than the traditional hotel industry.

On the other hand, criticism of the tourism related sharing economy has predominantly focused upon: the bypassing of government regulations by several peer-to-peer accommodation facilities, endangering consumer rights, product and service quality and safety, and disability compliance standards (Rauch and Schleicher, 2015); a parallel increase in consumer risks (Dredge and Gyimóthy, 2015); the extended loss of taxes, and unfair competition between hotels and peer-to-peer accommodation establishments (Lyons and Wearing, 2015); the subsequent potential for the sharing economy to pose an imminent threat to traditional hotels due to considerably lower prices (QTIC, 2014); the increased risk that employees have no security coverage when revenues from sharing economy activities become the sole source of income (Schor and Fitzmaurice, 2015); and the rise in a destination's social inequality, due to the higher level of social capital of its middle class compared with those who are unemployed, poor or live in peripheral (rural) areas (Dredge and Gyimóthy, 2015). All of the above highlight the necessity to further examine the aspects of the sharing economy in tourism and hospitality, as well as the complex relations that affect the tourism decision-making process.

\section{Peer-to-peer accommodation in Greece}

Greek peer-to-peer accommodation has a history of over a decade, but has only seen rapid development in the last five years (Hellenic Chamber of Hotels, 2015). The liberalisation of Greek private accommodation rental began in 2013, after a series of legislative governmental initiatives which aimed to reduce red-tape, simplify procedures, and facilitate enterprising growth amongst non-hotel accommodation establishments (OECD, 2016). This has resulted in a boom in apartments or houses offered for rent on online platforms (especially in the city of Athens), increasing their number throughout the country to several thousand properties within a very short period of time (Grreporter, 2014). The sharing economy has been considered by locals and Greek city authorities to be a powerful tool that provides an opportunity for individuals, enterprises and local societies alike to do more with what they have (Rinne, 2015). With special reference to Athens, peer-to-peer accommodation has 
seen rapid growth (during 2015 in some central areas [e.g. Koukaki] the growth was more than 800 per cent), establishing vacation rental apartments as a popular choice, due to the severe lack of hotel rooms in the city (Ta Nea, 2016).

Since the Greek economic crisis peer-to-peer accommodation has been an extremely versatile option, because tourism is the country's economic mainstay, everybody is looking for additional income generation, and 82 per cent of Greeks own their homes (Rinne, 2014). As a result, the recession has been a tremendous help to the development of the sharing economy in Greece due to the economic pressures and opportunities it helped to create (Killick, 2015). Despite the additional income that thousands of Greeks have generated during difficult times, the rapid development of peer-to-peer accommodation has created concerns for traditional Greek hotels, due to the fall in tourist numbers and profits, and for the Greek government because of the loss of taxes caused by high levels of tax evasion in peer-to-peer accommodation establishments (Greek Travel Pages, 2015); all of this during a period when the Greek economy was suffering from a shortage of economic resources, leading to extreme austerity, severe budget cuts, and resultant high levels of social unrest (Smith, 2016). More specifically, the selection of peer-to-peer accommodation by tourists has led to Greek hotels losing 12 million overnight stays, which translates to $€ 554$ million less in revenue, accounting for 15,000 job losses per year from the hotel sector, and a reduction in taxes of up to 350 million Euros per year from the Greek economy (Greek Travel Pages, 2015). As a result, from early June 2016, the Greek Tourism Ministry has introduced a cash tax on Airbnb-style rentals (following similar legislation imposed in Germany), and also threatens to fine those landlords who do not register the properties they advertise on Airbnb as businesses (Keep Talking Greece, 2016).

\section{Methods}

\section{Participants}

The study examined peer-to-peer accommodation adult holidaymakers, and took place between mid-December 2015 and mid-March 2016 in Athens, Greece. Structured English written questionnaires were distributed to respondents, since this was considered to be the most appropriate method of obtaining the primary data, due to the built in anonymity, the response rate, and the potential to examine a substantial portion of the population in a short period of time (Sekaran and Bougie, 2013). The questionnaires were left to the properties offered as peer-to-peer accommodation before the arrival of guests. The clients were asked to fill them in during their stay and leave them in the property after they leave. The average time for questionnaire completion was estimated to ten minutes. Listwise deletion (exclusion of the entire record from the analysis) was adopted as the least problematic method for missing data handling (Allison, 2001).

\section{Sample determination and collection}

Following research by Akis et al. (1996), when the population proportions are unknown, a conservative response format of 50/50 (negative perceptions exist amongst 50 per cent of the respondents, and 50 per cent have positive ones) should be chosen for sample size determination. A 95 per cent confidence level and 5 per cent sampling error were selected. The cumulative probability $(\mathrm{Z})$ from a t-table was 1.96 
(Sekaran and Bougie, 2013). According to Akis et al. (1996), the appropriate sample size is:

$$
N=\frac{Z^{2} \text { (hypothesis) }}{S^{2}} \Rightarrow N=\frac{1.96^{2}(0.5)(0.5)}{(0.5)^{2}} \Rightarrow N=384.16 \text { Rounded to } 400
$$

The sampling size calculation is independent of the overall population size, since the error is determined by the sampling size (Aaker and Day, 1990). In order to collect 400 questionnaires, 704 holidaymakers were invited to take part (response rate: 56.8 per cent), and 352 usable questionnaires were finally gathered, generating a statistical error of 5.22 per cent.

\section{Measures}

The research consists of 21 items using Likert Scale (1 strongly disagree / 5 strongly agree) statements (Table 1), and one socio-demographic (age) exclusion question. The questionnaire is based on prior research by Tussyadiah and Pesonen (n.d.) [five statements for social aspects; three statements for economic aspects; three statements for benefits], Sanchez et al. (2006) [four statements examining risks], Sparks and Browning (2011) and Gefen et al. (2003) [four statements focusing on trust], and Kim et al. (2008) [three statements dealing with the purchasing intention].

\section{Please insert Table 1}

Since the questionnaire was based on previous research, no extended pilot study had to be implemented. Instead, the first ten questionnaires were administered face-toface. The questionnaires were used for the identification of any aspects creating confusion to respondents, or statements that were perceived as vague. No such aspects have been identified. Therefore, these ten questionnaires were retained in the main study.

The study employs fuzzy-set Qualitative Comparative Analysis (fsQCA) for the examination of complex configurations. This theoretical method examines the potential of relationships to have a bearing upon the outcome of interest, as well as any possible binary set combinations generated from its predictors (Longest and Vaisey, 2008). QCA is a mixed-method technique because it is based on the combination of quantitative empirical testing (Longest and Vaisey, 2008) and qualitative inductive reasoning through the analysis of specific cases (Ragin, 2000). The logical complexity is handled through the allowance of the fact that different combinations of characteristics are able to generate different results through their combination with other conditions or events (Kent and Argouslidis, 2005). The research also estimated negated sets (presence or absence of a given condition) as suggested by Woodside and Zhang (2013). In these sets, the calculation of a membership is made by taking in the original fuzzy-set one minus the score of membership of the examined case (Skarmeas et al., 2014). The absence of an attribute is indicated by the symbol “ ".

Following Ordanini et al. (2014), in set theory a sub relation with fuzzy measures is consistent when in a specific causal set of attributions the scores of membership are consistently less or equal to the scores of membership in the outcome set. Accordingly, the coverage entails the assessment of the sufficient empirical 
importance of the configurations (Ordanini et al., 2014). Thus, consistency and coverage should be calculated as shown below:

$$
\begin{aligned}
& \text { Consistency }\left(X_{i} \leq Y_{i}\right)=\sum_{i}\left[\min \left(X_{i} ; Y_{i}\right)\right] / \sum_{i}\left(X_{i}\right) \\
& \text { Coverage }\left(X_{i} \leq Y_{i}\right)=\sum_{i}\left[\min \left(X_{i} ; Y_{i}\right)\right] / \sum_{i}\left(Y_{i}\right)
\end{aligned}
$$

where, for holidaymaker $i, X_{i}$ is the membership score in the $X$ configuration and $Y_{i}$ is the membership score for the outcome condition.

Skarmeas et al. (2014) suggest that a general asymmetry towards the respective relationships is present when the absolute values of all correlated coefficients are lower than .60. As illustrated in Table 2, all values are less than .60, thus the causal conditions produced by the alternative combinations can lead to the same outcome condition (Woodside, 2013). The research aim is to examine, through fsQCA, the formulation of purchasing intention by peer-to-peer holidaymakers. This is achieved through the estimation of complex antecedent conditions (causal recipes) leading to high membership in the following conditions: (i) social aspects (ii) economic aspects (iii) benefits (iv) risks, and (v) trust. In a recipe's membership score the case is the membership degree to which simple causal conditions of fuzzy-sets intersect and include the recipe (Woodside and Zhang, 2013). In the causal recipe, this intersection is the minimum score between the selected simple conditions (Skarmeas et al., 2014). Through the complexity combination this study assumes that non-parametric (nonlinear) relationships exist contrary to having Newtonian (linear) net effects.

\section{Please insert Table 2}

Woodside (2014, p.2499) indicates that the non-linear metric of consistency is analogous to the linear correlation metric, whilst the non-linear metric of coverage is analogous to the linear "coefficient of determination". A solution is acceptable and informative when the solution coverage of the model(s) is between .25 and .75 and the respective consistency is above .74 (Skarmeas et al., 2014).

\section{Implementation of fsQCA algorithms}

The current research aims to achieve a holistic view of its antecedents by employing fsQCA. It examines the complex antecedent conditions (causal recipes) that can provide a high membership. The research calibration has been implemented by a group of 38 randomly selected individual cases. For the evaluation of the holidaymakers' purchasing intentions (f_pi) the calibrated fuzzy-sets used were 'f_sa' for social aspects, 'f_ea' for economic aspects, 'f_b' for benefits, 'f_r' for risks, and 'f_t' for trust.

\section{Results}

\section{Sufficient complex statements}

As presented in Table 3 the findings suggest three solutions. The first sufficient complex statement (f_sa*f_ea* f_b* ff_r f_t) indicates that high social and economic aspects with low benefits, risks and trust can produce high purchasing intentions for 
peer-to-peer accommodation holidaymakers. The consistency of the solution in reference is at 0.853791 , whilst it appears to have the highest coverage of all three solutions $(0.428568)$. The second solution $\left(\sim \mathrm{f} \_s a^{*} \sim \mathrm{f} \_\right.$ea*f_b*f_r*f_t $)$suggests that high benefits, risks, and trust with low social and economic aspects can lead to high membership scores for purchasing intentions. This complex statement has the highest consistency (0.867290) and the lowest coverage (0.394731). The last solution $\left(\sim f \_s a * f \_e a * f \_b * \sim f \_r * \sim f \_t\right)$ that produces high membership in holidaymakers' purchasing intentions includes high economic aspects, and benefits with low social aspects, risks, and trust. Its consistency and coverage are 0.819387 and 0.403872 respectively. Overall, the solution consistency is good (0.847231) also providing a high coverage (0.512731). From Skarmeas et al. (2014), this result indicates that the solution is informative and acceptable.

\section{Please insert Table 3}

\section{Discussion}

An interesting discussion can be set out based upon the research findings. The first solution suggests that the socio-economic orientation of the holidaymakers defines their purchasing intentions. This finding is in agreement with the study by Tussyadiah and Pesonen (2015), suggesting that the social and economic appeals of peer-to-peer accommodation can influence changes in tourism activities and consumer decisionmaking. The findings also support the view that the nexus between economic and social aspects may determine the purchasing intentions of tourists, a relationship which is also strong enough to explain the factors determining the success of the accommodation sharing economy, and companies like Airbnb. It is useful to also highlight that, during times of turmoil (recession, the refugee crisis etc.), the consumers' wants and needs - and as a result their socio-economic orientation - may differ transforming consumption patterns and purchasing intentions.

Several studies, such as those by Aliouche et al. (2012), Gefen et al. (2003), Pappas (n.d.), Sparks and Browning (2011), highlight the importance of the association of benefits and risks, and consequently the formulation of trust in decision-making and purchasing intentions. The second solution confirms that the combination of these three factors (benefits, risks, trust) can lead tourists to the selection of peer-to-peer accommodation. These are also some of the dominant considerations of sharing economy accommodation consumers (Dredge and Gyimóthy, 2015; Goudin, 2016), despite the fact that the perceived risks of online purchasing are higher than those of traditional means of shopping (Kim and Qu, 2014; Ozturk, 2016). Still, the rapid growth of peer-to-peer accommodation indicates that the perceived benefits outweigh the potential risks, thus holidaymakers formulate high levels of trust that lead to sufficient intention to purchase the products in question.

The third solution focuses on price sensitivity. Accommodation establishments want to attract and retain customers since this is crucial to their survival and success (Ramanathan and Ramanathan, 2011). Especially during periods of economic turmoil the aspects of price and overall expenditure are important for accommodation selection, since consumers want to achieve the best possible 'value for money'. As a result, holidaymakers are likely to shift from traditional hotels to cheaper establishments. Thus, peer-to-peer accommodation has been significantly boosted by the current recession (Johanson, 2013), which has also presented new challenges and 
created the business need for effective price discrimination (Garbarino and Maxwell, 2010). This sufficient configuration highlights the importance of price and the expected benefits of peer-to-peer accommodation purchasing, providing substantial grounds for further understanding of tourist behaviour with special reference to times of recession.

\section{Confirmation of tenets}

As the findings indicate, the presented explanation in Table 3 of the three solutions is high (total coverage $=0.512731$ ). Moreover, economic aspects and benefits appear in two out of three solutions, whilst the other three appear in only one sufficient configuration. This finding further highlights the importance of economic aspects and benefits on tourism decision-making related to peer-to-peer accommodation. Social aspects appear in the first configuration, whilst risks and trust in the second one. These findings provide significant grounds for the confirmation of the first tenet (T1): The same attribute can determine a different purchasing intention for peer-to-peer accommodation holidaymakers depending on its configuration/interaction with other attributes.

As the results indicate (Table 3), the first sufficient configuration (f_sa*f_ea* f_b* f_r f_t ) includes two simple conditions, while the second ( ff_sa* $\left.\sim f \_e a * f \_b * f \_r * f \_t\right)$ and third solution ( f_sa*f_ea*f_b* f_r* fft) include three simple conditions. Therefore, all the sufficient configurations use at least two simple conditions, creating a complex configuration. This is also highlighted from previous studies such as Woodside (2014), and Olya and Altinay (2016), and supports the second tenet (T2): When two or more simple conditions create a complex configuration, an outcome condition can have a consistently high score (recipe principle).

It is important to clarify that QCA is based on cases instead of variables. As a result, the sufficient configurations concern: (i) an outcome dealing with the combination of the related variables, and (ii) the association of the groups of variables within the combination (Ordanini et al., 2014). As previously presented, the first solution is socio-economically oriented, revealing the importance of these aspects on peer-topeer accommodation holidaymakers. The second sufficient configuration is focused on the formulation of trust. The third solution expresses the price sensitivity, a very important issue especially during periods of economic turmoil. These results confirm the third tenet (T3): Complex configurations/interactions affect the purchasing intentions of peer-to-peer accommodation holidaymakers.

The research was based on contrarian case analysis (attributional inclusion or exclusion). For example, the results indicate that none of the examined conditions appears in all sufficient configurations, whilst all of them are present in at least one solution. As a result, the presence or absence of the examined conditions may have a positive or negative influence concerning tourist decision-making. Thus, these results support the fourth tenet (T4): The simple conditions within different combinations of configurations/interactions can positively or negatively affect the purchasing intentions of peer-to-peer accommodation holidaymakers.

Woodside (2014, p.2499) indicates that "The occurrences of different paths usually do not occur with the same frequency among the set of paths". This supports the principle of equifinality, which suggests that multiple paths can very well lead to the 
same outcome. As indicated in (Table 3), the outcome scores for the purchasing intentions of peer-to-peer accommodation holidaymakers are not actually high, leading to the confirmation of the fifth tenet (T5): A sufficient purchasing intention for peer-to-peer accommodation model is not necessary to occur by having a high outcome score (equifinality principle).

Finally, fsQCA analysis revealed that the coverage for all sufficient configurations is less than 1. As also indicated by Olya and Altinay (2016) this result indicates that each given recipe in not relevant for all cases. Therefore, the sixth tenet (T6) is also confirmed: When the Y scores are high, a given recipe for holidaymakers' purchasing intention of peer-to-peer accommodation is not relevant for all cases.

\section{fsQCA versus regression and Cramer's $V$}

Most tourism and hospitality studies examine statistical relationships using linear analysis, whilst the dominant method is regression and the use of a Structural Equation Model (SEM) (Pappas, n.d.). This study employed an additional analysis for comparison of the research findings with regression. However, it must be stressed that all attempts at comparison should be made with considerable caution, since fsQCA: implements distinct assumptions such as complex causality; focuses on different research objectives; establishes relations through cases instead of variables; and identifies configurations that provide sufficient and necessary conditions for a result of interest (Ordanini et al., 2014). Thus, all comparisons should be carefully implemented in order to avoid meaningless outcomes.

Validity and reliability findings revealed that the Kaiser-Meyer-Olkin (KMO) of Sampling Adequacy was $0.811(\mathrm{p}<.01)$, which is higher than the minimum requested 0.6 for further analysis. Cronbach's A was .729 [minimum acceptable is .7 (Nunnally, 1978)], whilst the Cronbach A per component and the factor analysis loadings are presented in Table 4. The model fit is as follows: $\chi^{2}=353.961$, difference $(\mathrm{df})=210$, $\chi^{2} / \mathrm{df}=1.685$ [acceptable value $0 \leq \chi^{2} / \mathrm{df} \leq 2$ (Schermelleh-Engel et al., 2003)], Comparative Fit Index (CFI) $=.907$ [acceptable value is when CFI is close to 1.0 (Weston and Gore, 2006)], Root-Mean-Square Error of Approximation (RMSEA) $=.48$ [acceptable value is when RMSEA $<.5$ (Browne and Cudeck, 1993)], and Standardised Root-Mean-Square Residual (SRMR) $=.74$ [acceptable value is when SRMR $<.8$ (Hu and Bentler, 1999)]. All effects were statistically significant, whilst the overall model's $\mathrm{R}^{2}=.344$. Moreover, all five constructs (social aspects, economic aspects, benefits, risks, trust) appear to directly impact the purchasing intentions of peer-to-peer accommodation holidaymakers, confirming SEM results. The measures are presented in Figure 1. The comparison of fsQCA with regression highlights the appropriateness of the former for complexity aspects in tourism and hospitality, since it is apparent that fsQCA is more efficient than regression and can adequately explain the relationships between the examined constructs.

\section{Please insert Table 4}

\section{Please insert Figure 1}

Further to regression, the study has implemented Cramer's V tests, as presented in Table 5. According to Burns and Burns (2008), Cramer's V varies from 0 (no association) to 1 (complete association). The results indicate that wherever Cramer's 
$\mathrm{V}$ tests are statistically significant $(\mathrm{p}<.05)$, the effect size is weak to moderate, varying from .153 (weak/minimally acceptable: .15<V<.20) to .222 (moderate/acceptable: $.20<\mathrm{V}<.25$ ). For once more fsQCA appears to be more efficient than Cramer's V, since it better illustrates the influence of the examined constructs on consumers' purchasing intention.

\section{Please insert Table 5}

\section{Fit and predictive validity}

Most of the researchers focusing on the examination of specific models implement model fit (Gigerenzer and Brighton, 2009) in order to ensure that the data can create substantial grounds for the relationships amongst the observed variables and their respective factors (Pappas, 2015b). Thus, only very few studies concentrate on predictive validity (Papatheodorou and Pappas, n.d.; Wu et al., 2014), proposing that a good model is not necessarily dependent on a relevant good fit to observations (Gigerenzer and Brighton, 2009). This study proceeds from fit to predictive validity for the examined models. In order to do so, it follows the process described by Wu et al. (2014), and Olya and Altinay (2016). More specifically, the sample was divided in a holdout and a modelling subsample, since the patterns of tourism decisions are perceived to be consistent indicators for the production of high scores, using half of the overall sample. The configural models of the holdout sample were examined by using the modelling subsample. The algorithm combination of the holdout sample was similar with the results from fsQCA in all the sample. Finally the holdout sample was tested through the use of the modelling subsample. The overall consistency was .823 $(\mathrm{C} 1>.74)$ and the coverage was $.487(.75>\mathrm{C} 2>.25)$. According to the findings the suggested model's predictive validity is good.

\section{Managerial implications}

The research findings highlight the complex process of holidaymakers' purchasing intentions with special reference to the sharing economy. In addition, they pinpoint the importance of fsQCA when these complex conditions are evaluated. The analysis has produced three sufficient configurations concerning peer-to-peer accommodation tourist decision-making: (i) socio-economic orientation (ii) formulation of trust, and (iii) price sensitivity. These results can assist both destination authorities and locals who offer their properties using peer-to-peer accommodation processes to better understand the complexity of tourists' shopping decision-making. It is essential for tourism industry practitioners to better comprehend the elements, processes and conditions required in order to develop sufficient strategies and policies for their business, especially during periods of crisis (Paraskevas et al., 2013). This research can also assist traditional accommodation establishments to further comprehend the reshaping of the tourist market, the transformation of supply and demand, and the new trends concerning the decision-making processes of holidaymakers, especially during periods of economic crisis.

In terms of purchasing intentions with regard to peer-to-peer accommodation, the use of fsQCA can help us to further comprehend the concept of complexity and better present the crucial aspects that affect holidaymakers' decision-making. The research also presents the disadvantages of using regression and Cramer's V (the methods of conventional linear analysis which are most often adopted) to highlight the complexity of tourists' behavioural associations, showing that it fails to sufficiently 
examine the patterns involved in tourist decisions in a holistic way. The findings illustrate the importance of financial issues, since the economic aspects are included in two solutions (socio-economic orientation; price sensitivity), especially when the research is conducted during recession conditions. The transformation of tourist decision-making and the considerably increased 'value for money' patterns in accommodation shopping need to be seriously taken into consideration by both businesses and destinations. Online shopping and the sharing economy are here to stay. Moreover, periods of turmoil triggered by various causes (e.g. political instability, recession, the refugee crisis, and terrorism) will continue to exist, and possibly increase in the foreseeable future, reshaping global tourism and hospitality dynamics (Papatheodorou and Pappas, n.d.). Thus, it would be advisable for accommodation providers (traditional hotels and sharing economy establishments) to establish a basis for cooperation amongst themselves, instead of identifying concerns and conflicts as happened in Germany (Payton, 2016) and Greece (Smith, 2016). It is essential for them to further understand the rapid transformation of purchasing patterns, and the necessary added value in the provided products and services that can substantially influence the buying behaviour of tourists. In addition, destination authorities should play the role of guarantors for the minimisation of these conflicts, since a problematic accommodation industry directly reflects on the destination's success and the well-being of its inhabitants.

The complex systems of tourist decision-making need to be further examined by destinations and their accommodation providers. The implementation of fsQCA can assist peer-to-peer accommodation and traditional hotels to better understand the behavioural patterns of tourists, and improve their strategies and operational actions especially during periods of instability. For example, they could establish different methods of attracting holidaymakers, depending on their decision-making complexity and the clarification of their final purchasing intentions. Especially during periods of crisis, companies need to have the ability to scan the business environment and sufficiently identify the signals that are relevant to them (Paraskevas and Altinay, 2013). Undoubtedly, the tourists' perceptions concerning 'value for money' and trust formulation connected with their perceived and actual consumption power should be located at the epicentre of business environmental scanning. The three solutions generated by this research indicate that the purchasing intentions of peer-to-peer accommodation holidaymakers are dependent on the specific characteristics of the individuals, and the way they are combined. Thus, fsQCA can be used as a tool for the examination and analysis of tourist trends and decision-making, as well as to provide more informed decisions to destination and accommodation entrepreneurs giving them the ability to manage their business more successfully.

\section{Limitations and future research}

Despite the theoretical and methodological contribution of the study, it does have a number of limitations. The first limitation concerns the methodological strength of the research. Since only a handful of studies have implemented fsQCA in the service sector (Wu et al., 2014) and it is new in the tourism domain (Papatheodorou and Pappas, n.d.), its full potential has yet to be realised. Thus, fsQCA needs to be further examined in multiple tourism contexts involving the theories of chaos and complexity, while further exploratory evaluation may provide useful insights. Another limitation derives from the potential examination of other attributes, resulting in the production of different outcomes. Thus, any generalisation of outcomes should be 
made with caution, whilst different aspects of tourist behaviour, socio-demographic characteristics, and decision-making also have to be evaluated. Third, the research only examines the perceptions of peer-to-peer accommodation holidaymakers. A useful comparison between these people and tourists selecting traditional accommodation (along with their individual characteristics) would help us to further understand the purchasing intentions of consumers.

The efficiency of fsQCA in examining and providing sufficient complex configurations, suggesting different pathways leading to the same outcome, means that it is likely to be implemented along with other methodological techniques such as conjoint analysis. Furthermore, the application of fsQCA could provide a better understanding of other influential factors of consumer purchasing intention, like psychological fluctuations, financial vulnerability, uncertainty levels of shopping patterns etc. All of the above create a promising domain for the use and growth of fsQCA in tourism and hospitality research.

\section{References}

Aaker, D., and Day, G. (1990), Marketing research, Wiley, New York, NY.

Akis, S., Peristianis, N., and Warner, J. (1996), "Residents' attitudes to tourism development: the case of Cyprus”, Tourism Management, Vol. 17 No. 7, pp.481494.

Aliouche, E.H., Kaen, F., and Schlentrich, U. (2012), “The market performance of franchise stock portfolios”, International Journal of Contemporary Hospitality Management, Vol. 24 No. 5, pp.791-809.

Allison, P.D. (2001), Missing data. Sage Publications, Thousand Oaks.

Baggio, R. (2008), "Symptoms of complexity in a tourism system”, Tourism Analysis, Vol. 13 No. 1, pp.1-20.

Baggio, R., and Sainaghi, R. (2011, "Complex and chaotic tourism systems: Towards a quantitative approach”, International Journal of Contemporary Hospitality Management, Vol. 23 No. 6, pp.840-861.

Bakos, J.Y. (1997), "Reducing buyer search costs: Implications for Electronic Marketplaces”, Management Science, Vol. 43 No. 12, pp.1676-1692.

Beritelli, P., and Schegg, R. (2016), "Maximizing online bookings through a multichannel-strategy: Effects of interdependencies and networks”, International Journal of Contemporary Hospitality Management, Vol. 28 No. 1, pp.68-88.

Botsman, R., and Rogers, R. (2010), What's mine is yours: How collaborative consumption is changing the way we live, Harper Collins Business, London.

Boukas, N., and Ziakas, V. (2014), "A chaos theory perspective of destination crisis and sustainable tourism development in islands: the case of Cyprus”, Tourism Planning and Development, Vol. 11 No. 2, pp.191-208.

Browne M.W., and Cudeck, R. (1993), “Alternative ways of assessing model fit”, in Bollen, K.A. and Long J.S. (Ed.), Testing Structural Equation Models, Sage, Beverly Hills CA, pp.136-162.

Burns, R.B., and Burn, R.A. (2008), Business research methods and statistics using SPSS, Sage, London.

Cheng, M. (2016), “Sharing economy: A review and agenda for future research”, International Journal of Hospitality Management, Vol. 57, pp.60-70.

Clampet, J. (2015), “What's an Airbnb listing worth in 2015?” Skift, Published $19^{\text {th }}$ June, available at: http://skift.com/2015/06/19/whats-an-airbnb-listing-worth-in2015/ (Accessed $3^{\text {rd }}$ August 2016). 
Dredge, D., and Gyimóthy, S. (2015), “The collaborative economy and tourism: critical perspectives, questionable claims and silenced voices” Tourism Recreation Research, Vol. 40 No. 3, pp.286-302.

Faulkner, B., and Russell, R. (1997), "Chaos and complexity in tourism: In search of a new perspective”, Pacific Tourism Review, Vol. 1, pp.93-102.

Faulkner, B., and Russell, R. (2000), "Turbulence, chaos and complexity in tourism systems: A research direction for the new millennium”, in Faulkner, R. Moscardo, G. and Laws, E. (Ed.), Tourism in the 21st century: Lessons from experience, Continuum, London, pp.328-349.

Gansky, L. (2010), The Mesh: Why the Future of Business is Sharing, Portfolio Trade, London.

Garbarino, E., and Maxwell, S. (2010), “Consumer response to norm-breaking pricing events in e-commerce”, Journal of Business Research, Vol. 63 No. 9-10, pp.1066-1072.

Gefen, D., Karahanna, E., and Straub, D.W. (2003), "Trust and TAM in online shopping: An integrated model”, MIS Quarterly Vol. 27 No. 1, pp.51-90.

Gigerenzer, G., and Brighton, H. (2009), "Homo heuristics: Why biased minds make better inferences”, Topics in Cognitive Science, Vol. 1, pp.107-143.

Goudin, P. (2016), The cost of non-Europe in the sharing economy: Economic, social and legal challenges and opportunities. European Parliamentary Research Service, Brussels.

Greek Travel Pages (2015), “The 'Sharing Economy’ in tourism deprives Greece of millions of Euros”, GTP headlines, Published $8^{\text {th }}$ October, available at: http://news.gtp.gr/2015/10/08/sharing-economy-tourism-deprives-greecemillions/ (Accessed $30^{\text {th }}$ July 2016).

Grreporter (2014), "The sharing economy is here to stay", Grreporter, Published $25^{\text {th }}$ November, available at: http://www.grreporter.info/en/sharing_economy_here_stay/12015 (Accessed 3rd July 2016).

Heinrichs, H. (2013), "Sharing economy: a potential new pathway to sustainability”, Gaia, Vol. 22 No. 4, pp.228-231.

Hellenic Chamber of Hotels (2015), Sharing economy and the Greek tourism and hospitality sector. Hellenic Chamber of Hotels, Athens.

Hock, D. (1999). Birth of a chaordic age. Barret-Koehler Publishers, Inc., San Francisco, CA.

Hu, L., and Bentler, P.M. (1999), "Cutoff criteria for fit indexes in covariance structure analysis: Conventional criteria versus new alternatives”, Structural Equation Modelling: A Multidiciplinary Journal, Vol. 6 No. 1, pp.1-55.

Johanson, M. (2013), “The sharing economy: What you need to know before you sign up”, International Business Times, Published $20^{\text {th }}$ May, available at:

http://www.ibtimes.com/sharing-economy-what-you-need-know-you-sign1269057 (Accessed 30 th July 2016).

Keep Talking Greece (2016), "Greece to tax and fine Airbnb-style vacation rentals, force landlords to register as business", Keep Talking Greece, Published, $15^{\text {th }}$ June, available at: http://www.keeptalkinggreece.com/2016/06/15/greece-to-taxand-fine-airbnb-style-vacation-rentals-force-landlords-to-register-as-business/ (Accessed $3^{\text {rd }}$ August, 2016).

Kellert, S. (1993), In the wake of chaos: Unpredictable order in dynamical systems, University of Chicago Press, Chicago IL. 
Kent, R.A., and Argouslidis, P.C. (2005), "Shaping business decisions using fuzzy-set analysis”, Journal of Marketing Management, Vol. 21 No. 5-6, 641-658.

Killick, R. (2015), “'Sharing economy' companies like Uber and Airbnb aren't really 'sharing' anything”, International Business Times, Published $7^{\text {th }}$ October, available at: http://uk.businessinsider.com/sharing-economy-companies-likeuber-and-airbnb-arent-really-sharing-anything-2015-10? $\mathrm{r}=\mathrm{USandIR}=\mathrm{T}$ (Accessed $3^{\text {rd }}$ August 2016).

Kim, D.J., Donald, L.F., and Rao, H.R. (2008), “A trust-based consumer decisionmaking model in electronic commerce: the role of trust, perceived risk and their antecedents”, Decision Support Systems, Vol. 44 No. 2, pp.544-564.

Kim, J., Yoon, Y., and Zo, H. (2015), "Why people participate in the sharing economy: a social exchange perspective”, Proceedings of Pacific Asia Conference on Information Systems (PACIS), 6-9 July, Singapore.

Kim, M., and Qu, H. (2014), “Travelers’ behavioral intention toward hotel selfservice kiosks usage”, International Journal of Contemporary Hospitality Management, Vol. 26 No. 2, pp.225-245.

Konrad, A., and Mac, R. (2014), "Airbnb cofounders to become first sharing economy billionaires as company nears $\$ 10$ billion valuation”, Forbes, Published $20^{\text {th }}$ March, available at: http://www.forbes.com/sites/alexkonrad/2014/03/20/airbnbcofounders-are-billionaires/\#7cf6dda541ab (Accessed 30 ${ }^{\text {th }}$ July 2016).

Koopman, C., Mitchell, M., and Thierer, A. (2014), "The sharing economy and consumer protection regulation: The case for policy change”, Mercatus Working Paper, George Mason University, Arlington, VA.

Lashinsky, A. (2015), “Uber: an oral history.” Fortune, Published $3^{\text {rd }}$ June, available at: http://fortune.com/2015/06/03/uber-an-oral-history/ (Accessed 30 ${ }^{\text {th }}$ July 2016).

Laws, E., and Prideaux, B. (2005), "Crisis management: A suggested typology”, Journal of Travel and Tourism Marketing, Vol. 19 No. 2-3, pp.1-8.

Levy, D. (1994), "Chaos theory and strategy: Theory, application, and managerial implications”, Strategic Management Journal, Vol. 15 No. 2, pp.167-178.

Lindenberg, S. (2001), Intrinsic motivation in a new light”, KYKLOS, Vol. 54 No. 2/3, pp.317-342.

Longest, K., and Vaisey, S. (2008), "Fuzzy: A Program for Performing Qualitative Comparative Analyses (QCA) in STATA”, The STATA Journal, Vol. 8 No. 1, pp.79-104.

Lyons, K., and Wearing, S. (2015), The sharing economy issues, impacts, and regulatory responses in the context of the NSW visitor economy. NSW Business Chamber, Sydney.

Martin, C.J. (2016), "The sharing economy: A pathway to sustainability or a nightmarish form of neoliberal capitalism?” Ecological Economics, Vol. 121, pp.149-159.

McDonald, J.R. (2009), “Complexity science: an alternative world view for understanding sustainable tourism development”, Journal of Sustainable Tourism, Vol. 17 No. 4, pp.455-471.

Meyer, A.D., Gaba, V., and Colwell, K.A. (2005), “Organizing far from equilibrium: Nonlinear change in organizational fields”, Organization Science, Vol. 16 No. 5, pp.456-473.

Möhlmann, M. (2015), “Collaborative consumption: determinants of satisfaction and the likelihood of using a sharing economy option again”, Journal of Consumer Behaviour, Vol. 14 No. 3, pp.193-207. 
Morozov, E. (2013), The 'sharing economy' undermines workers rights, Published $14^{\text {th }}$ October, available at:

http://evgenymorozov.tumblr.com/post/64038831400/the-sharing-economyundermines-workers-rights (Accessed 30th July 2016).

Nadler, S.S.N. (2014), The sharing economy: What is it and where is it going? Massachusetts Institute of Technology, Cambridge, MA.

Nunnally, J.C. (1978). Psychometric theory. $2^{\text {nd }}$ Eds., McGraw-Hill, New York, NY.

OECD (2016), Policies for the tourism sharing economy: OECD tourism trends and policies 2016. Organisation for Economic Co-operation and Development, OECD Publishing, Paris.

Olmedo, E., and Mateos, R. (2015), "Quantitative characterization of chaordic tourist destination”, Tourism Management, Vol. 47, pp.115-126.

Olya, H.G., and Altinay, L. (2016), "Asymmetric modeling of intention to purchase tourism weather insurance and loyalty”, Journal of Business Research, Vol. 69 No. 8, pp.2791-2800.

Ordanini, A., Parasuraman, A., and Rubera, G. (2014), "When the recipe is more important than the ingredients: A Qualitative Comparative Analysis (QCA) of service innovation configurations”, Journal of Service Research, Vol. 17 No. 2, pp.134-149.

Ozturk, A.B. (2016), "Customer acceptance of cashless payment systems in the hospitality industry”, International Journal of Contemporary Hospitality Management, Vol. 28 No. 4, pp.801-817.

Papatheodorou, A., and Pappas, N. (n.d), "Economic recession job vulnerability and tourism decision-making: A Qualitative Comparative Analysis,” Journal of Travel Research, Article in press.

Pappas, N. (2015a), "Marketing hospitality industry in an era of crisis”, Tourism Planning and Development, Vol. 11 No. 3, pp.333-349.

Pappas, N. (n.d.), "Risks and marketing in online transactions: A Qualitative Comparative Analysis”, Current Issues in Tourism, Article in Press.

Pappas, N. (2015b), “Achieving competitiveness in Greek accommodation establishments during recession”, International Journal of Tourism Research, Vol. 17 No. 4, pp.375-387.

Paraskevas, A., Altinay, L., Mclean, J., and Cooper, C. (2013), "Crisis knowledge in tourism: Flows and governance”, Annals of Tourism Research, Vol. 41, pp.130152.

Paraskevas, A., and Altinay, L. (2013), "Signal detection as the first line of defence in tourism crisis management”, Tourism Management, Vol. 34, pp.158-171.

Payton, M. (2016), "Berlin stops Airbnb renting apartments to tourists to protect affordable housing” The Independent, Published $1^{\text {st }}$ May, available at: http://www.independent.co.uk/news/world/europe/airbnb-rentals-berlin-germanytourist-ban-fines-restricting-to-protect-affordable-housing-a7008891.html (Accessed 30th July 2016).

QTIC (2014), The sharing economy: How it will impact the tourism landscape and what businesses can do. Queensland Tourism Industry Council, Brisbane.

Ramanathan, U., and Ramanathan, R. (2011), “Guests' perceptions on factors influencing customer loyalty: An analysis for UK hotels”, International Journal of Contemporary Hospitality Management, Vol. 23 No. 1, pp.7-25.

Rauch, D.E., and Schleicher, D. (2015), "Like uber, but for local governmental policy: the future of local regulation of the sharing economy”, George Mason Law and Economics, Research Paper, No. 2015-01. 
Richardson, L. (2015), “Performing the sharing economy”, Geoforum, Vol. 67, pp.121-129.

Rinne, A. (2014), "Sharing economy in cities: moving towards a more inclusive urban future”, The Guardian, Published $26^{\text {th }}$ June, available at:

https://www.theguardian.com/sustainable-business/circular-economy-policycities-inclusive-urban (Accessed $4^{\text {th }}$ August 2016)

Rinne, A. (2015), “2015: The year of the sharing economy for cities?” World Economic Forum, Published $21^{\text {st }}$ January, available at: https://www.weforum.org/agenda/2015/01/2015-the-year-of-the-sharingeconomy-for-cities/ (Accessed $3^{\text {rd }}$ August 2016)

Russel, R., and Faulkner, B. (2004), "Entrepreneurship, chaos and the tourism area lifecycle”, Tourism Management, Vol. 31 No. 3, pp.556-579.

Sanchez, J., Callarisa, L., Rodriguez, R.M., and Moliner, M.A. (2006), "Perceived value of the purchase of a tourism product”, Tourism Management, Vol. 27 No. 3, pp.394-409.

Schermelleh-Engel, K., Moosbrugger, H., and Müller, H. (2003), “Evaluating the fit of structural equation models: Test of significance and descriptive goodness-of-fit measures”, Methods of Psychological Research - Online, Vol. 8 No. 2, pp.23-74.

Schofield, H. (2014), "Short-let apartments spark Paris row as Airbnb thrives", BBC News, published $26^{\text {th }}$ December, available at: http://www.bbc.co.uk/news/worldeurope-30580295 (Accessed 30th July 2016).

Schor, J.B., and Fitzmaurice, C.J. (2015), "Collaborating and connecting: the emergence of the sharing economy”, in: Reisch, L. and Thogersen, J. (Ed.), Handbook of Research on Sustainable Consumption, Edward Elgar, Cheltenham, pp. 410-425.

Seeger, M. (2002), "Chaos and crisis: Propositions for a general theory of crisis communication”, Public Relations Review, Vol. 28 No. 4, pp.329-337.

Sekaran, U., and Bougie, R. (2013), Research methods for business: A skill building approach. Wiley and Sons, Chennai.

Sigala, M. (n.d.), "Collaborative commerce in tourism: implications for research and industry”, Current Issues in Tourism, Article in press.

Skarmeas, D., Leonidou, C.N., and Saridakis, C. (2014), "Examining the role of CSR skepticism using fuzzy-set qualitative comparative analysis. Journal of Business Research, Vol. 67, 1796-1805.

Smith, H. (2016), "Greek MPs approve toughest austerity measures yet amid rioting”, The Guardian, Published $9^{\text {th }}$ May, available at:

https://www.theguardian.com/world/2016/may/08/rioters-take-to-the-streetsahead-of-greek-austerity-vote (Accessed 3rd August 2016).

Sparks, B.A., and Browning, V. (2011), "The impact of online reviews on hotel booking intentions and perception of trust”, Tourism Management, Vol. 32 No. 6, pp.1310-1323.

Ta Nea (2016), Koukaki is $5^{\text {th }}$ in Airbnb list with the best neighbourhoods in the world, Ta Nea newspaper, Published $15^{\text {th }}$ January, available at: http://www.tanea.gr/news/greece/article/5326545/pempto-to-koykaki-sthn-listaths-airbnb-me-tis-kalyteres-geitonies-toy-kosmoy/ [In Greek] (Accessed $3^{\text {rd }}$ August 2016).

The Local (2016), Hundreds of hosts ignore Berlin’s Airbnb ban, The Local, Published $3^{\text {rd }}$ May, available at: http://www.thelocal.de/20160503/100s-of-flatsstill-available-after-berlins-airbnb-ban (Accessed 30th July, 2016). 
Tussyadiah, I.P. (2016), "Factors of satisfaction and intention to use peer-to-peer accommodation”, Vol. 55, pp.70-80.

Tussyadiah, P., and Pesonen J. (n.d.), "Impacts to peer-to-peer accommodation use of travel patterns", Journal of Travel Research, Article in press.

Weston, R., and Gore, P.A.Jr. (2006), “A Brief Guide to Structural Equation Modeling”, The Counseling Psychologist, Vol. 34 No. 5, pp.719-751.

Woodside, A.G. (2013), "Moving beyond multiple regression analysis to algorithms: Calling for adoption of a paradigm shift from symmetric to asymmetric thinking in data analysis and crafting theory”, Journal of Business Research, Vol. 66 No. 4, pp.463-472.

Woodside, A.G. (2014), "Embrace•perform•model: Complexity theory, contrarian case analysis, and multiple realities”, Journal of Business Research, Vol. 67, 2495-2503.

Woodside, A.G., and Zhang, M. (2013), “Cultural diversity and marketing transactions: Are market integration, large community size, and world religions necessary for fairness in ephemeral exchanges?” Psychology and Marketing, Vol. 30 No. 3, pp.263-276.

Wu, L.Y., Chen, K.Y., Chen, P.Y., and Tung, P.J. (2016), "Revisiting associations between specific asset investment and loyal and cooperative behavior: A complexity theory perspective”, Journal of Business Research, Vol. 69 No. 9, pp.3545-3552.

Wu, P.L., Yeh, S.S., Huan, T.C., and Woodside, A.G. (2014), “Applying complexity theory to deepen service dominant logic: Configural analysis of customer experience-and-outcome assessments of professional services for personal transformations” Journal of Business Research, Vol. 67 No. 8, pp.1647-1670.

Xitong G., Vogel, D., Zhou, Z., Zhang, X., and Che H. (2009), "Chaos theory as a lens for interpreting blogging” Journal of Management Information Systems, Vol. 26 No. 1, pp.101-127.

Zahra, A., and Ryan, C. (2007), "From chaos to cohesion - Complexity in tourism structures: An analysis of New Zealand's regional tourism organizations" Tourism Management, Vol. 28 No. 3, pp.854-862.

Zervas, G., Proserpio D., and Buyers, J. (2016), "The rise of the sharing economy: Estimating the impact of Airbnb on the hotel industry", George Mason Law and Economics, Research Paper, No. 2013-16. 


\begin{tabular}{|c|c|c|c|}
\hline & Statement & Mean & Std. Dev. \\
\hline & Social Aspects & & \\
\hline SA1 & $\begin{array}{l}\text { I used peer-to-peer accommodation rentals because I would like } \\
\text { to get to know people from the local neighbourhoods. }\end{array}$ & 3.91 & .746 \\
\hline SA2 & $\begin{array}{l}\text { I used peer-to-peer accommodation rentals because I would like } \\
\text { to have a more meaningful interaction with the hosts. }\end{array}$ & 3.91 & .692 \\
\hline SA3 & $\begin{array}{l}\text { I used peer-to-peer accommodation rentals because I would like } \\
\text { to support local residents. }\end{array}$ & 3.86 & 715 \\
\hline \multirow[t]{2}{*}{ SA4 } & $\begin{array}{l}\text { I used peer-to-peer accommodation rentals because I would like } \\
\text { to get insider tips on local attractions. }\end{array}$ & 3.63 & .693 \\
\hline & Economic Aspects & & \\
\hline EA1 & $\begin{array}{l}\text { I used peer-to-peer accommodation rentals because it saved me } \\
\text { money. }\end{array}$ & 4.38 & .642 \\
\hline EA2 & $\begin{array}{l}\text { I used peer-to-peer accommodation rentals because it helps } \\
\text { lower my travel cost. }\end{array}$ & 4.17 & .487 \\
\hline \multirow[t]{2}{*}{ EA3 } & $\begin{array}{l}\text { I used peer-to-peer accommodation rentals because I would like } \\
\text { to have higher quality accommodation for less money. }\end{array}$ & 4.19 & .533 \\
\hline & Benefits & & \\
\hline B1 & Peer-to-peer accommodation expands my destination selection. & 4.09 & .710 \\
\hline B2 & $\begin{array}{l}\text { Peer-to-peer accommodation increases the frequency with } \\
\text { which I travel. }\end{array}$ & 3.88 & 956 \\
\hline \multirow[t]{2}{*}{ B3 } & $\begin{array}{l}\text { Peer-to-peer accommodation increases the length of stay in the } \\
\text { destinations I select. }\end{array}$ & 3.91 & .823 \\
\hline & Risks & & \\
\hline $\mathrm{R} 1$ & $\begin{array}{l}\text { I think about the risk of not having made a good purchase } \\
\text { bearing in mind the price I pay. }\end{array}$ & 3.62 & .830 \\
\hline R2 & $\begin{array}{l}\text { When booking peer-to-peer accommodation I consider the risks } \\
\text { in the way the product is organised. }\end{array}$ & 3.74 & .786 \\
\hline R3 & $\begin{array}{l}\text { When booking peer-to-peer accommodation I consider the risk } \\
\text { that I will not receive what I expected. }\end{array}$ & 3.77 & .815 \\
\hline \multirow[t]{2}{*}{$\mathrm{R} 4$} & $\begin{array}{l}\text { When booking peer-to-peer accommodation I consider its } \\
\text { quality compared with other relevant accommodation products. }\end{array}$ & 3.96 & .822 \\
\hline & Trust & & \\
\hline T1 & The peer-to-peer accommodation I booked is trustworthy. & 4.07 & .659 \\
\hline $\mathrm{T} 2$ & $\begin{array}{l}\text { The peer-to-peer accommodation I booked fills me with } \\
\text { confidence. }\end{array}$ & 4.05 & .709 \\
\hline T3 & $\begin{array}{l}\text { My impression is that the peer-to-peer accommodation I booked } \\
\text { is of good quality. }\end{array}$ & 3.99 & .712 \\
\hline \multirow[t]{2}{*}{$\mathrm{T} 4$} & The peer-to-peer accommodation I booked fulfils my needs. & 3.90 & .776 \\
\hline & Intention to Purchase & & \\
\hline IP1 & I am likely to book peer-to-peer accommodation. & 3.95 & .601 \\
\hline IP2 & $\begin{array}{l}\text { I am likely to recommend peer-to-peer accommodation to my } \\
\text { friends. }\end{array}$ & 4.07 & .718 \\
\hline IP3 & $\begin{array}{l}\text { I am likely to make another booking of peer-to-peer } \\
\text { accommodation if I am satisfied with this one. }\end{array}$ & 4.12 & .717 \\
\hline
\end{tabular}


Table 2: Correlation matrix

\begin{tabular}{|c|c|c|c|c|c|c|c|}
\hline & Measures & 1 & 2 & 3 & 4 & 5 & 6 \\
\hline 1 & Social Aspects & 1.00 & & & & & \\
\hline 2 & Economic Aspects & -.098 & 1.00 & & & & \\
\hline 3 & Benefits & $.210^{\mathrm{b}}$ & -.073 & 1.00 & & & \\
\hline 4 & Risks & $-.229^{b}$ & $.131^{\mathrm{a}}$ & $-.307^{b}$ & 1.00 & & \\
\hline 5 & Trust & $-.242^{\mathrm{b}}$ & $.114^{\mathrm{a}}$ & $-.257^{\mathrm{b}}$ & $.315^{\mathrm{b}}$ & 1.00 & \\
\hline 6 & Purchasing Intention & $.237^{\mathrm{b}}$ & -.082 & $.259^{\mathrm{b}}$ & $-.220^{\mathrm{b}}$ & $-.204^{\mathrm{b}}$ & 1.00 \\
\hline
\end{tabular}


Table 3: Complex solutions for purchasing intentions

\begin{tabular}{|c|c|c|c|}
\hline Complex Solution & Raw Coverage & $\begin{array}{c}\text { Unique } \\
\text { Coverage }\end{array}$ & Consistency \\
\hline \multicolumn{4}{|c|}{ Model: f_pi=f(f_sa,f_ea,f_b,f_r,f_t) } \\
\hline f_sa*f_ea* ff_b* $\sim$ f_r $\sim f \_t$ & 0.428568 & 0.164269 & 0.853791 \\
\hline$\sim \bar{f}$ sa* $\sim f$ fea*f_b*f_r*f_t & 0.394731 & 0.149275 & 0.867290 \\
\hline$\sim f \_s a * f$ ea*f_b $* \sim f$ rr $*$ f_t & 0.403872 & 0.114260 & 0.819387 \\
\hline Solution Coverage: 0.512731 & \multicolumn{3}{|c|}{ Solution Consistency: 0.847231} \\
\hline
\end{tabular}


Table 4: Cronbach’s Alpha and loadings produced by factor analysis

\begin{tabular}{cccc}
\hline & Statements & Cronbach's Alpha & Loadings \\
\hline Social & SA1 & .744 & .556 \\
Aspects & SA2 & & .670 \\
& SA3 & & .575 \\
& SA4 & & .612 \\
\hline Economic & EA1 & .721 & .704 \\
Aspects & EA2 & & .658 \\
& EA3 & & .669 \\
\hline Benefits & B1 & .726 & .798 \\
& B2 & & .717 \\
& B3 & & .671 \\
\hline Risks & R1 & .734 & .803 \\
& R2 & & .823 \\
& R3 & & .746 \\
& R4 & & .736 \\
\hline Trust & T1 & .741 & .783 \\
& T2 & & .787 \\
& T3 & & .830 \\
Intention to & T4 & & .743 \\
Purchase & IP1 & .735 & .837 \\
& IP2 & & .851 \\
\hline & IP3 & &
\end{tabular}


Table 5: Cramer's V tests

\begin{tabular}{lccc}
\hline & $\chi^{2}$ & Cramer's V & Sig. \\
\hline Intention* Social Aspects & 109.850 & .198 & .015 \\
Intention*Econ. Aspects & 48.787 & .153 & .041 \\
Intention*Benefits & 138.047 & .222 & .000 \\
Intention*Risks & 125.224 & .213 & .354 \\
Intention*Trust & 100.687 & .191 & .000 \\
\hline
\end{tabular}


Figure 1: Standardised coefficients: Purchasing intention in peer-to-peer accommodation

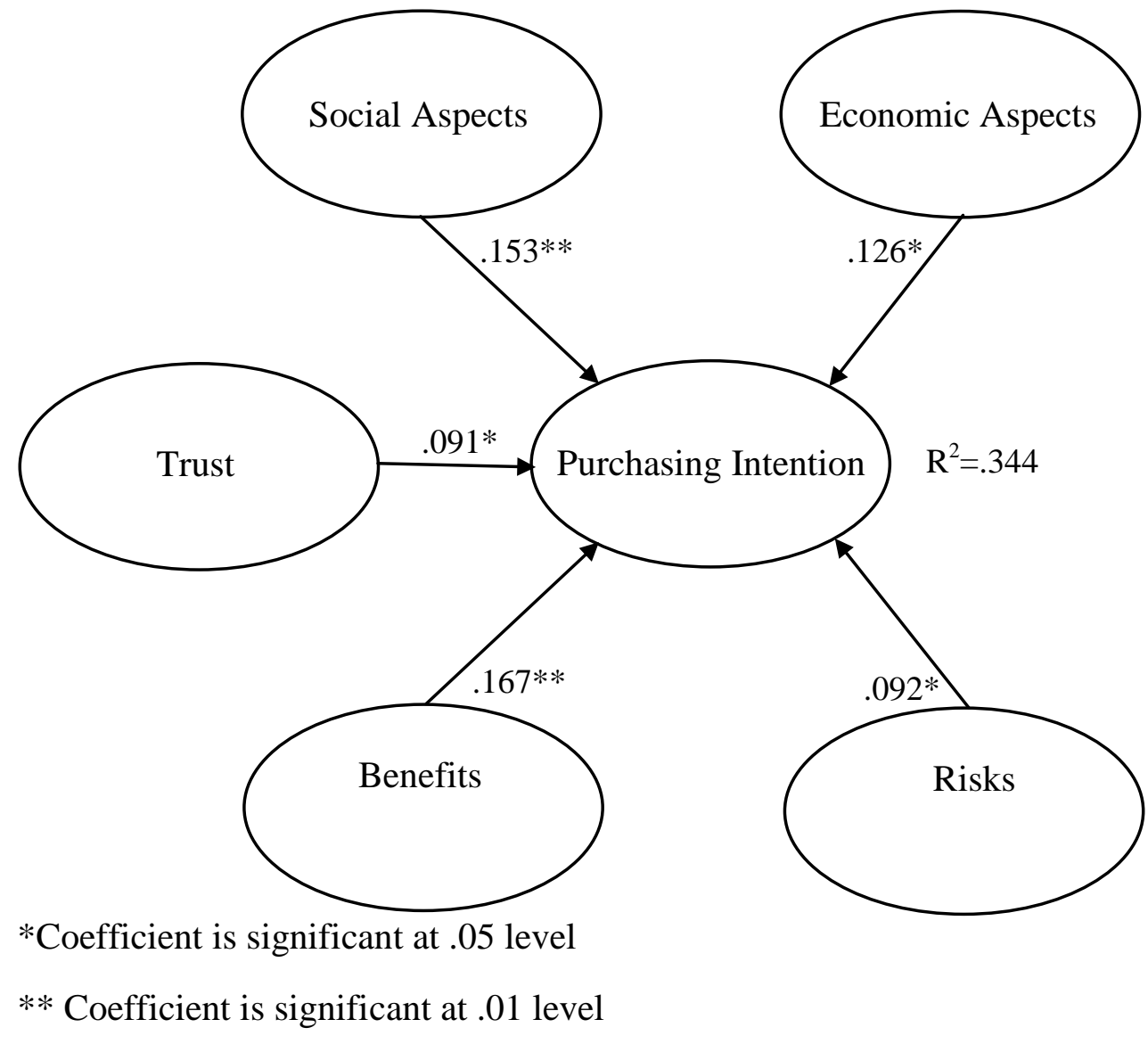

